\section{Mistérios do futebol}

\section{Cristovão Tezza}

Romancista, contista, cronista e ensaísta, Cristovão Tezza nasceu, em 1952, em Lages, Santa Catarina, mas, acompanhando seus pais, mudou-se aos oito anos de idade para Curitiba, onde vive até hoje. Esta cidade é cenário de boa parte de sua literatura, como nos romances Trapo (1988), Juliano Pavollini (1991), O fantasma da infância (1992), Uma noite em Curitiba (1995), Breve espaço (1998) e O fotógrafo (2004).

É autor de mais de 20 livros publicados no Brasil. Suas obras já foram traduzidas em 18 países, como China, Estados Unidos, Noruega, México, Eslovênia e Inglaterra. Foi cronista semanal do jornal curitibano Gazeta do Povo, onde publicou esta crônica, que bem nos diz sobre o que é o futebol.

Fonte: site do autor - http://www.cristovaotezza.com.br
As melhores perguntas são as que não têm resposta. Por exemplo: qual o mistério do futebol? Não sei. Olhando de longe, é um grupo de marmanjos uniformizados participando de uma gincana, todos correndo atrás de uma bola sobre um gramado retangular marcado com linhas brancas. A bola deve ser levada a pontapés para dentro de uma rede sustentada por traves. Só um dos rapazes pode segurar a bola com a mão. Quem controla tudo é um sujeito mais velho, de uniforme diferente - quando esse homem trila um apito, o que faz com frequência, todo mundo para de correr e olha para ele. Às vezes ele tira do bolso um cartão amarelo e mostra para alguém, que quase sempre dá uma risadinha e faz "não" com a cabeça, as mãos na cintura. Se calha de ele pegar um cartão vermelho, que vale mais, o sujeito sai furioso do campo e não volta. Em torno do gramado sempre tem umas arquibancadas cheias de gente berrando e sacudindo bandeiras. Quando a bola vai para dentro da rede - o que é relativamente raro -, as pessoas de parte das arquibancadas se levantam todas ao mesmo tempo e fazem uma gritaria demorada, incompreensível e feliz; outra parte fica quieta e triste. 
Imagino que, pela descrição, vocês entenderam mais ou menos o que é o futebol, mas alguma coisa ficou faltando. É a mesma sensação que tenho quando tentam me explicar o beisebol: um bando de quarentões barrigudos de ceroulas ridículas com bonés da cabeça que, de vez em quando, jogam uma bolinha de criança para acertar a cabeça de um sujeito agachado com um capacete no rosto e uma luva deformada na mão; de costas para ele fica um cara ameaçador balançando um perigoso porrete na mão. De vez em quando um deles larga tudo e dispara a correr meio que sem direção (o campo é torto), tentando agarrar a bolinha que voa. Parece que é isso.

Claro, faltou tudo. No caso do futebol, eu me pergunto por que esse esporte, sendo simples como uma brincadeira de criança, é capaz de me transtornar tão completamente. Crise do Senado, queda de avião, gripe suína - passo correndo pela parte séria do jornal e me detenho profundamente na recuperação de Alex Mineiro e no gênio de Paulo Baier, o Zidane da Baixada. Grito com os jogadores como se eles pudessem me ouvir. Proponho substituições tão óbvias que só o burro do técnico não entende. Pior: fico feliz se o juiz não marca uma falta escancarada do meu time e furioso se ele apita um pênalti contra que de fato houve. Tudo que é moralmente errado me atrai: faço cálculos detalhados na classificação do Brasileiro, no desespero de ver o Atlético um ou dois degraus acima, enquanto com o rabo do olho investigo, mesquinho, a queda do Coritiba - equipe de grandes amigos meus, e até da minha própria mãe - com uma felicidade secreta mas angustiada, porque afinal amanhã tudo pode virar do avesso. Por que o futebol faz isso comigo?

Não sei. 